\title{
DAYA TERIMA KONSUMEN TERHADAP PRODUK MINUMAN HASIL FERMENTASI CUKA APEL DAN WORTEL
}

\author{
Consumer Received Payment to Drinking Products of Fermentation \\ Vinegar Apple and Carrot
}

\author{
A. Zainul Arifin dan Sri Hariningsih Pratiwi \\ Dosen Universitas Merdeka Pasuruan \\ email : ahmadunmer23@yahoo.com
}

\begin{abstract}
Apple is a fruit that is often used as a raw material for making fermented acid drinks commonly referred to as apple vinegar. Apple vinegar is one type of functional beverage. The combination of apple vinegar with honey has been studied previously and is reported to cure diseases such as colds, infections, rheumatism and arthritis. The aimed of this study is to determine the acceptance of consumers of beverage products fermented apple vinegar and carrots. This experiment used a single randomized design. Organoleptic test data was analyzed by non parametric statistic method using Friedman Test. The results showed that the best treatment combination on the organoleptic test was obtained from a combination on $5 \mathrm{~kg}$ and 5 $\mathrm{kg}$ carrot fermentation treatment (blended together) with a mean value of panelist favorability to taste on 4.13; color on 4.10 and aroma on 3.93.
\end{abstract}

Keywords: apple, carrot, vinegar

\begin{abstract}
ABSTRAK
Apel merupakan buah yang sudah sering digunakan sebagai bahan baku pembuatan minuman asam hasil fermentasi yang biasa disebut dengan cuka apel. Cuka apel sendiri merupakan salah satu jenis minuman fungsional. Kombinasi cuka apel dengan madu sudah pernah diteliti sebelumnya dan dilaporkan dapat menyembuhkan berbagai penyakit seperti masuk angin, infeksi, rematik dan radang sendi. Tujuan dari penelitian ini adalah untuk mengetahui daya terima konsumen terhadap produk minuman hasil fermentasi cuka apel dan wortel. Percobaan ini menggunakan rancangan acak tunggal. Data uji organoleptik dianalisis dengan metode statistik non parametrik menggunakan Uji Friedman. Hasil penelitian menunjukkan bahwa kombinasi perlakuan terbaik pada uji organoleptik didapatkan dari kombinasi perlakuan fermentasi apel 5 $\mathrm{kg}$ dan wortel 2,5 $\mathrm{kg}$ (diblender bersama) dengan rerata nilai tingkat kesukaan panelis terhadap rasa sebesar 4,13; warna sebesar 4,10 dan aroma sebesar 3,93.
\end{abstract}

Kata kunci: apel, wortel, cuka

\section{PENDAHULUAN}

Apel merupakan salah satu buah yang banyak disukai masyarakat di Indonesia dan dapat ditemui sepanjang tahun karena tidak tergantung oleh musim tertentu. Apel dapat dikonsumsi langsung atau diolah menjadi beberapa produk olahan. Apel dapat dikalengkan atau dibuat jus. Buah apel digiling untuk memproduksi sider (nonalkohol dan manis), dan disaring untuk dibuat jus. Apel juga difermentasi untuk menghasilkan sider (alkoholik dan keras), siderkin, dan cuka. Melalui distilasi, berbagai minuman beralkohol dapat dibuat, seperti applejack, Calvados, dan wine apel (Anonymous, 2016 ${ }^{\mathrm{a}}$ ). Apel juga bermanfaat sebagai pengobatan untuk penyakit diabetes (Hlebowicz et al., 2007)

Wortel adalah tumbuhan biennial (siklus hidup 12-24 bulan) yang menyimpan karbohidrat dalam jumlah besar, berbunga 
pada tahun kedua. Batang bunga tumbuh setinggi sekitar $1 \mathrm{~m}$, dengan bunga berwarna putih, dan rasa yang manis langu. Bagian yang dapat dimakan dari wortel adalah bagian umbi atau akarnya. Wortel dapat dimakan dengan berbagai cara. Pada wortel mentah hanya $3 \% \beta$-ririencha yang dilepaskan selama proses pencernaan (Suwandi, 1991), proses ini dapat ditingkatkan hingga $39 \%$ melalui pulping, memasaknya dan menambahkan minyak sawit (Datt et al., 2012). Bisa juga dengan cara di buat jus wortel dan kandungan vitaminnya hampir sama dengan wortel yang dimakan begitu saja (Anonymaous, 2016 b $^{\mathrm{b}}$, selain itu wortel dapat dijadikan olahan untuk pangan fungsional (Rachman dan Histifarina, 2005).

Pengembangan lebih lanjut menjadi produk pangan (minuman) komersial memerlukan penelitian mendalam untuk memperoleh data yang pasti mengenai metode tradisional yang jarang dipakai pada kalangan industri minuman. Sheehy dan Morrissey (1998) dalam Winarti dan Nurdjanah (2005) menyimpulkan bahwa keberhasilan pengembangan pangan fungional bergantung pada banyak faktor, antara lain keamanan, efikasi, rasa, kemudahan dan nilai (value) dari produk tersebut. Keunggulan yang paling penting adalah bahwa produk tersebut harus aman dan klaim manfaatnya nyata.

\section{BAHAN DAN METODE}

\section{Bahan}

Bahan yang digunakan dalam penelitian ini adalah buah apel dan wortel, Gula 500 gram, dekstrosa 100 gram, dan Natural yeast komersial (Saccharomyces cerevisiae) 25 gram yang diperoleh di daerah Kabupaten Pasuruan.

\section{Alat}

Alat-alat yang digunakan dalam analisis berupa timbangan digital, panci steanless steel, (XP-1500, Jerman), vortex (Barnstead), tabung reaksi (Pyrex), gelas ukur $50 \mathrm{ml}$ (Pyrex), erlenmeyer $250 \mathrm{ml}$
(Pyrex), labu ukur $100 \mathrm{ml}$ (Pyrex), pipet mikro10-100 $\mu$ l (Soccorex), pipet volum 1 $\mathrm{ml}$ (Assistance), pipet volum $5 \mathrm{ml}$ (HBG), beaker glass $250 \mathrm{ml}$ (Pyrex), corong pemisah $100 \mathrm{ml}$ (Schott-Duran), rak kayu tabung reaksi.

\section{Rancangan Penelitian}

Rancangan yang digunakan dalam penelitian ini menggunakan rancangan acak tunggal dengan 4 (empat) level perbandingan bahan apel dan wortel yaitu : $\mathrm{P} 1=$ fermentasi apel $5 \mathrm{~kg}$ tanpa wortel (kontrol); P2 = fermentasi apel $5 \mathrm{~kg}$ dan wortel 2,5 kg (diblender bersama); P3 = fermentasi apel $5 \mathrm{~kg}$ ditambah ekstrak sari wortel 2,5 kg setelah proses tahap 1; dan P4 $=$ fermentasi apel $5 \mathrm{~kg}$ ditambah ekstrak sari wortel $2,5 \mathrm{~kg}$ setelah proses tahap 2 .

Masing-masing level diulang sebanyak tujuh kali sehingga dihasilkan 28 satuan percobaan. Perlakuan yang memiliki indeks efektifitas berdasarkan paramater uji organoleptik (warna, rasa dan aroma) dan uji kimia (kadar alkohol, total asam, kadar gula reduksi dan kandungan vitamin) terbaik dari perlakuan diatas yang dinilai layak secara teknis.

\section{Pengamatan}

Pengamatan dilakukan terhadap produk akhir minuman hasil fermentasi cuka apel-wortel meliputi uji organoleptik (warna, rasa dan aroma) dari 30 responden.

\section{Analisis Data}

Data hasil uji organoleptik dianalisis dengan metode statistik non parametrik menggunakan Uji Friedman.

\section{HASIL DAN PEMBAHASAN}

\section{Warna}

Hasil uji organoleptik menyajikan bahwa rerata ranking kesukaan panelis terhadap warna dari kombinasi perlakuan fermentasi cuka apel dengan tambahan wortel berkisar antara 3,03-4,10. Semakin tinggi rerata ranking kesukaan panelis, maka tingkat kesukaan panelis terhadap warna 
semakin besar. Tabel 1 memperlihatkan rerata ranking tingkat kesukaan panelis terhadap warna.

Tabel 1 memperlihatkan rerata nilai kesukaan panelis terhadap warna pada berbagai kombinasi perlakuan mempunyai nilai terendah sebesar 3,03 dari kombinasi perlakuan fermentasi apel $5 \mathrm{~kg}$ ditambah ekstrak sari wortel $2,5 \mathrm{~kg}$ setelah proses tahap 2. Nilai tertinggi tingkat kesukaan panelis terhadap warna sebesar 4,10 didapatkan dari fermentasi apel $5 \mathrm{~kg}$ dan wortel $2,5 \mathrm{~kg}$ (diblender bersama).

Hasil analisis Uji Friedman $(\alpha=0,05)$ berdasarkan uji perbandingan pada berbagai kombinasi perlakuan memberikan pengaruh nyata terhadap rerata kesukaan warna terhadap kombinasi perlakuan fermentasi apel dengan wortel. Kombinasi perlakuan terbaik tingkat kesukaan panelis terhadap warna diperoleh dari kombinasi perlakuan fermentasi apel $5 \mathrm{~kg}$ dan wortel $2,5 \mathrm{~kg}$ (diblender bersama), warna yang ditimbulkan oleh produk minuman ini sangat menarik yaitu seperti perpaduan antara kuning bening.

\section{Rasa}

Hasil uji organoleptik menyajikan bahwa rerata ranking kesukaan panelis terhadap rasa dari kombinasi perlakuan fermentasi cuka apel dengan tambahan wortel berkisar antara 2,43-4,13. Semakin tinggi rerata ranking kesukaan panelis, maka tingkat kesukaan panelis terhadap rasa semakin besar. Tabel 2 memperlihatkan rerata ranking tingkat kesukaan panelis terhadap rasa.

Tabel 2 memperlihatkan rerata nilai kesukaan panelis terhadap rasa pada berbagai kombinasi perlakuan mempunyai nilai terendah sebesar 3,03 dari kombinasi perlakuan fermentasi apel $5 \mathrm{~kg}$ ditambah ekstrak sari wortel $2,5 \mathrm{~kg}$ setelah proses tahap 2. Nilai tertinggi tingkat kesukaan panelis terhadap rasa sebesar 4,13 didapatkan dari fermentasi apel $5 \mathrm{~kg}$ dan wortel $2,5 \mathrm{~kg}$ (diblender bersama).

Tabel 1. Rerata tingkat kesukaan panelis terhadap warna

\begin{tabular}{lc}
\multicolumn{1}{c}{ Kombinasi perlakuan } & Rerata tungkat kesukaan panelis \\
\hline Fermentasi apel $5 \mathrm{~kg}$ tanpa wortel (kontrol) & 2,53 \\
$\begin{array}{l}\text { Fermentasi apel } 5 \mathrm{~kg} \text { dan wortel } 2,5 \mathrm{~kg} \text { (diblender } \\
\text { bersama) }\end{array}$ & 4,10 \\
$\begin{array}{l}\text { Fermentasi apel } 5 \mathrm{~kg} \text { ditambah ekstrak sari } \\
\text { wortel 2,5 kg setelah proses tahap 1 }\end{array}$ & 4,03 \\
$\begin{array}{l}\text { Fermentasi apel } 5 \text { kg ditambah ekstrak sari } \\
\text { wortel 2,5 kg setelah proses tahap 2 }\end{array}$ & 3,03 \\
\hline
\end{tabular}

Tabel 2. Rerata tingkat kesukaan panelis terhadap rasa

\begin{tabular}{lc}
\hline \multicolumn{1}{c}{ Kombinasi perlakuan } & Rerata tungkat kesukaan panelis \\
\hline Fermentasi apel $5 \mathrm{~kg}$ tanpa wortel (kontrol) & 2,43 \\
$\begin{array}{l}\text { Fermentasi apel } 5 \mathrm{~kg} \text { dan wortel } 2,5 \mathrm{~kg} \text { (diblender } \\
\text { bersama) }\end{array}$ & 4,13 \\
$\begin{array}{l}\text { Fermentasi apel } 5 \mathrm{~kg} \text { ditambah } \\
\text { wortel 2,5 kg setelah proses tahap } 1\end{array}$ & 4,00 \\
$\begin{array}{l}\text { Fermentasi apel } 5 \mathrm{~kg} \text { ditambah } \\
\text { wortel 2,5 kg setelah proses tahap 2 }\end{array}$ & 3,03 \\
\hline $\begin{array}{l}\text { Hasil analisis Uji Friedman }(\alpha=0,05) \\
\text { sari }\end{array}$ & berdasarkan uji perbandingan pada berbagai
\end{tabular}


kombinasi perlakuan memberikan pengaruh nyata terhadap rerata kesukaan rasa terhadap kombinasi perlakuan fermentasi cuka apel dengan tambahan wortel. Kombinasi perlakuan terbaik tingkat kesukaan panelis terhadap rasa diperoleh dari kombinasi perlakuan fermentasi apel $5 \mathrm{~kg}$ dan wortel 2,5 kg (diblender bersama). Menurut panelis penambahan wortel $2,5 \mathrm{~kg}$, rasa yang ditimbulkan oleh produk minuman ini adalah sangat tepat, karena tidak terlalu asam.

\section{Aroma}

Hasil uji organoleptik menyajikan bahwa rerata ranking kesukaan panelis terhadap aroma dari kombinasi perlakuan fermentasi cuka apel dengan tambahan wortel berkisar antara 2,33-3,93. Semakin tinggi rerata ranking kesukaan panelis, maka tingkat kesukaan panelis terhadap aroma semakin besar. Tabel 3 memperlihatkan rerata ranking tingkat kesukaan panelis terhadap aroma.

Tabel 3 memperlihatkan rerata nilai kesukaan panelis terhadap aroma pada berbagai kombinasi perlakuan mempunyai nilai terendah sebesar 2,33 dari kombinasi perlakuan fermentasi apel $5 \mathrm{~kg}$ ditambah ekstrak sari wortel $2,5 \mathrm{~kg}$ setelah proses tahap 2. Nilai tertinggi tingkat kesukaan panelis terhadap aroma sebesar 3,93 didapatkan dari kombinasi fermentasi apel 5 $\mathrm{kg}$ dan wortel 2,5 $\mathrm{kg}$ (diblender bersama).

Hasil analisis Uji Friedman $(\alpha=0,05)$ berdasarkan uji perbandingan pada berbagai kombinasi perlakuan memberikan pengaruh nyata terhadap rerata kesukaan aroma terhadap kombinasi perlakuan fermentasi cuka apel dengan tambahan wortel. Kombinasi perlakuan terbaik tingkat kesukaan panelis terhadap aroma diperoleh dari kombinasi perlakuan fermentasi apel 5 $\mathrm{kg}$ dan wortel 2,5 $\mathrm{kg}$ (diblender bersama). Menurut panelis penambahan wortel $2,5 \mathrm{~kg}$, aroma yang ditimbulkan oleh produk minuman ini sangat netral, artinya baunya tidak terlalu menyengat.

\section{Pemilihan Perlakuan Terbaik}

Penentuan perlakuan terbaik berbagai kombinasi perlakuan fermentasi cuka apel dengan tambahan wortel dilakukan dengan menggunakan metode indeks efektivitas (Susrini, 2005). Hasil uji perlakuan terbaik didapatkan dari kombinasi perlakuan fermentasi apel $5 \mathrm{~kg}$ dan wortel $2,5 \mathrm{~kg}$ (diblender bersama) dengan nilai produk sebesar 1,007 dengan karakteristik sebagai berikut: rerata nilai tingkat kesukaan panelis terhadap rasa 4,13 ; warna 4,10 dan aroma 3,9345 .

Tabel 3. Rerata tingkat kesukaan panelis terhadap aroma

\begin{tabular}{lc}
\hline \multicolumn{1}{c}{ Kombinasi perlakuan } & Rerata tungkat kesukaan panelis \\
\hline Fermentasi apel $5 \mathrm{~kg}$ tanpa wortel (kontrol) & 3,87 \\
$\begin{array}{l}\text { Fermentasi apel } 5 \mathrm{~kg} \text { dan wortel } 2,5 \mathrm{~kg} \text { (diblender } \\
\text { bersama) }\end{array}$ & 3,93 \\
$\begin{array}{l}\text { Fermentasi apel } 5 \mathrm{~kg} \text { ditambah ekstrak sari } \\
\text { wortel 2,5 kg setelah proses tahap 1 }\end{array}$ & 2,90 \\
$\begin{array}{l}\text { Fermentasi apel } 5 \mathrm{~kg} \text { ditambah ekstrak sari } \\
\text { wortel 2,5 kg setelah proses tahap 2 }\end{array}$ & 2,33 \\
\hline
\end{tabular}

KESIMPULAN
Kombinasi perlakuan terbaik secra organoleptik diperoleh dari kombinasi 
perlakuan fermentasi apel $5 \mathrm{~kg}$ dan wortel $2,5 \mathrm{~kg}$ (diblender bersama) dengan nilai produk sebesar 1,007 dengan karakteristik sebagai berikut: rerata nilai tingkat kesukaan panelis terhadap rasa 4,13; warna 4,10 dan aroma 3,93.

\section{DAFTAR PUSTAKA}

Anonymous. (2016 ${ }^{\mathrm{a}}$. Apel. https://id. wikipedia.org/wiki/Apel. diakses tanggal 14 April 2016.

Anonymous. $\left(2016^{\mathrm{b})}\right.$. Wortel. https://id. wikipedia.org/wiki/Wortel. diakses tanggal 14 April 2016.

Datt, K. S., Swati K, Narayan S. T. and Surekha A. (2012). Chemical composition, functional properties and processing of carrot-a review. Association of Food Scientists \& Technologists (India). J Food Science Technology 49 (1) : 22-32.
Hlebowicz, J., Darwiche, G., Björgell, O. and Almér, L.O. (2007). Effect of Apple Cider Vinegar on Delayed Gastric Emptying in Patients with Type 1 Diabetes Mellitus: A Pilot Study. BMC Gastroenterology 7 (46): 1-6.

Rachman, A. dan D. Histifarina. (2005). Potensi Sayuran Wortel dan Produk Olahannya Sebagai Pangan Fungsional. Seminar Pangan Fungsional.

Suwandi, U. (1991). Manfaat Beta-Karoten Bagi Kesehatan, Pusat Penelitian dan Pengembangan PT. Kalbe Farma, Jakarta.

Winarti, C. dan Nurdjanah, N. (2005). Peluang Tanaman Rempah dan Obat sebagai Sumber Pangan Fungsional. Jurnal Litbang Pertanian 24(2):47-55. 